\title{
Hydrogeochemical analysis for Tasuj plain aquifer, Iran
}

\author{
Ata Allah Nadiri ${ }^{1,2}$, Asghar Asghari Moghaddam ${ }^{1, *}$, \\ Frank T-C Tsai ${ }^{2}$ and ElHam FiJAni ${ }^{1,2}$ \\ ${ }^{1}$ Department of Geology, University of Tabriz, 29 Bahman Boulevard, Tabriz, East Azerbaijan, Iran. \\ ${ }^{2}$ Department of Civil and Environmental Engineering, Louisiana State University, 3418G Patrick F. Taylor Hall, \\ Baton Rouge, LA 70803, USA. \\ ${ }^{*}$ Corresponding author.e-mail: Moghaddam@tabrizu.ac.ir
}

This study investigated the hydrogeochemical processes of groundwater in the Tasuj plain, Iran. The Tasuj plain is one of the 12 marginal plains around Urmia Lake which is currently under a critical ecological condition. In the last decades, the Tasuj plain aquifer suffered from severe groundwater level declination and caused degradation of groundwater quality. To better understand hydrogeochemical processes in the Tasuj plain, this study adopted graphical methods and multivariate statistical techniques to analyze groundwater samples. A total of 504 groundwater samples was obtained from 34 different locations (qanats, wells, and springs) over 12 years (1997-2009) and analyzed for 15 water quality parameters. From the results, the Piper diagram indicated four groundwater types and the Stiff diagram showed eight different sources of groundwater samples. The Durov diagram identified five major hydrogeochemical processes in the aquifer. However, hierarchical cluster analysis (HCA) identified five water types in the groundwater samples because HCA was able to analyze more chemical and physical data than graphical methods. The HCA result was checked by discriminant analysis and found consistency in all samples that were classified into correct groups. Using factor analysis, we identified three factors that accounted for $81.6 \%$ of the total variance of the dataset. Based on the high factor loadings of the variables, factors 1 and 2 reflected the natural hydrogeochemical processes and factor 3 explained the effect of agricultural fertilizers and human activities in the Tasuj plain. Dendrograms from 2000 to 2009 were studied to understand the temporal variation of groundwater quality. Comparing the distributions of groundwater types in 2000 and 2009, we found that the mixing zone was expanded. This may be due to artificial groundwater recharge in the recharge area and the effect of inverse ion exchange in the discharge area.

\section{Introduction}

Groundwater is a vital water resource to the arid and semi-arid areas in Iran. Recent increases in agricultural activities in Iran have caused groundwater to become the main water source for agriculture, industry and public uses. This study focuses on the Tasuj plain aquifer, one of the endangered aquifers around Urmia Lake (the third largest saline lake in the world), where groundwater level has considerably declined due to large groundwater withdrawals. The continuation of groundwater level declination at its current rate could cause desiccation of Urmia Lake and an ecosystem disaster to its surrounding area. Therefore, groundwater quality monitoring and protection are essential to sustain the Tasuj plain aquifer. For this purpose, a fundamental understanding of hydrogeochemical processes and hydrogeological conditions for an aquifer system is important (Adams et al. 2001;

Keywords. Graphical method; hydrogeochemistry; multivariate statistics analysis; Tasuj plain aquifer. 
Khazaei et al. 2006; Al-Shaibani 2008; Asghari Moghaddam and Fijani 2008; Hossain et al. 2010).

Hydrogeochemical processes are influenced by many factors, such as geogenic factors (i.e., rockwater interaction) and anthropogenic activities (i.e., agricultural, industrial and domestic activities). Recent research showed the importance of investigating the impacts of various factors on hydrogeochemistry (Chae et al. 2004; Dragon 2006; Cloutier et al. 2008). In this study, we adopt graphical and multivariate statistical methods to better understand the hydrogeochemical processes in the Tasuj plain aquifer.

Graphical methods (e.g., Piper diagram, Durov diagram, Stiff diagram, etc.) are commonly used to interpret hydrogeochemical processes (Piper 1944; Durov 1948; Stiff 1951; Lloyd 1965; Hem 1986; Hounslow 1995; Schwartz and Zhang 2003). Piper diagrams can be used to deduce groundwater types (Asghari Moghaddam and Fijani 2009). An expanded Durov diagram (Lloyd and Heathcote 1985) improves the Piper diagram by providing a better display of different types of water as well as important hydrochemical processes, such as ion exchange, simple dissolution and mixing of waters of different qualities (Singhal and Gupta 1999). A Stiff diagram compares analytical data in pairs and infers types of source rocks (Stiff 1951; Hounslow 1995). Although the graphical methods are commonly used to interpret hydrogeochemical processes, they have several limitations as they cannot be used to analyze neutral chemical species (e.g., $\mathrm{SiO}_{2}$ and $\mathrm{NO}_{3}^{-}$) and nonchemical data (e.g., temperature) (Voudouris et al. 1997).

Multivariate statistical methods (e.g., factor analysis (FA), hierarchical clustering analysis (HCA) and discriminant analysis (DA)) are able to complement the limitations of the graphical methods for hydrogeochemical process interpretation (Johnson and Wichern 1992; Reghunath et al. 2002; Singh et al. 2004; Chen et al. 2007; Cloutier et al. 2008). Multivariate statistical analysis is able to explain the correlation among a large number of variables and reduce the number of variables into a small number of factors without loss of essential information (Jackson 1991). Laaksoharju et al. (1999) adopted multivariate statistical analysis to simplify and organize a large number of variables to gain meaningful insights. In multivariate statistical methods, factor analysis was frequently used to investigate hydrogeochemical origins (Voudouris et al. 2000; Lambrakis et al. 2004). Factor analysis was also applied for investigating groundwater contamination (Grande et al. 1996; Dragon 2006; Jiang et al. 2009). Clustering analysis was used as a classification technique for hydrogeochemical type investigation and the interpretation of their origin (Cloutier et al. 2008). Discriminant analysis was used to determine the variables, which discriminate two or more naturally occurring groups. This method can verify if the groups are classified correctly by cluster analysis (Lambrakis et al. 2004; Singh et al. 2004). In summary, multivariate statistical methods have several advantages. They can correlate chemical and nonchemical data, incorporate more chemical and physical variables (e.g., $\mathrm{EC}, \mathrm{pH}$ and temperature), and identify relationships between variables and samples (Matalas and Reiher 1967; Dalton and Upchurch 1978).

In order to better understand the Tasuj plain aquifer, in this study we conduct hydrogeological and hydrogeochemical investigations on the groundwater data obtained from the Tasuj plain aquifer using graphical methods and multivariate statistical methods. The objectives of the study are:

- to investigate the aquifer hydrogeological and geophysical conditions,

- to identify types and origins of groundwater resources,

- to identify major hydrogeochemical processes,

- to identify hydrochemical factors that have influence on groundwater quality, and

- to identify groundwater type variation through the time.

\section{Study area}

The Tasuj basin shown in figure 1 is located about $100 \mathrm{~km}$ northwest of the city of Tabriz, in the northwest region of Iran. The basin is a subbasin of the Urmia Lake basin. The Tasuj basin is about $559.32 \mathrm{~km}^{2}$. This includes $302.67 \mathrm{~km}^{2}$ of the Tasuj plain and $256.65 \mathrm{~km}^{2}$ of Mishu Mountain. The study area is surrounded by Urmia Lake (south), Mishu Mountain (north), Salmas Plain (west) and Shabestar Plain (east). The study area contains the city of Tasuj and 15 other villages. Agriculture is the main economic activity in the area.

The highest elevation of the Tasuj basin is $3133 \mathrm{~m}$ above mean sea level (amsl) at the peak of Alamdar Mountain and the lowest elevation is $1274 \mathrm{~m}$ amsl near Urmia Lake. Based on de Martonne (1925) and Emberger (1930), the prevailing climate in the Tasuj plain is semiarid-cold. Average annual precipitation is about $232.7 \mathrm{~mm}$ (Tasuj climatological station, 2000-2009) (Research Center of Agriculture and Natural Resources of East Azerbaijan Province 2010). The highest and lowest precipitation occurs in the spring and summer seasons, respectively. The mean daily temperature at the Tasuj climatological station $(1411 \mathrm{~m}$ amsl) varies from $-11.33^{\circ} \mathrm{C}$ (in January) to $33^{\circ} \mathrm{C}$ (in August). The annual temperature average is 


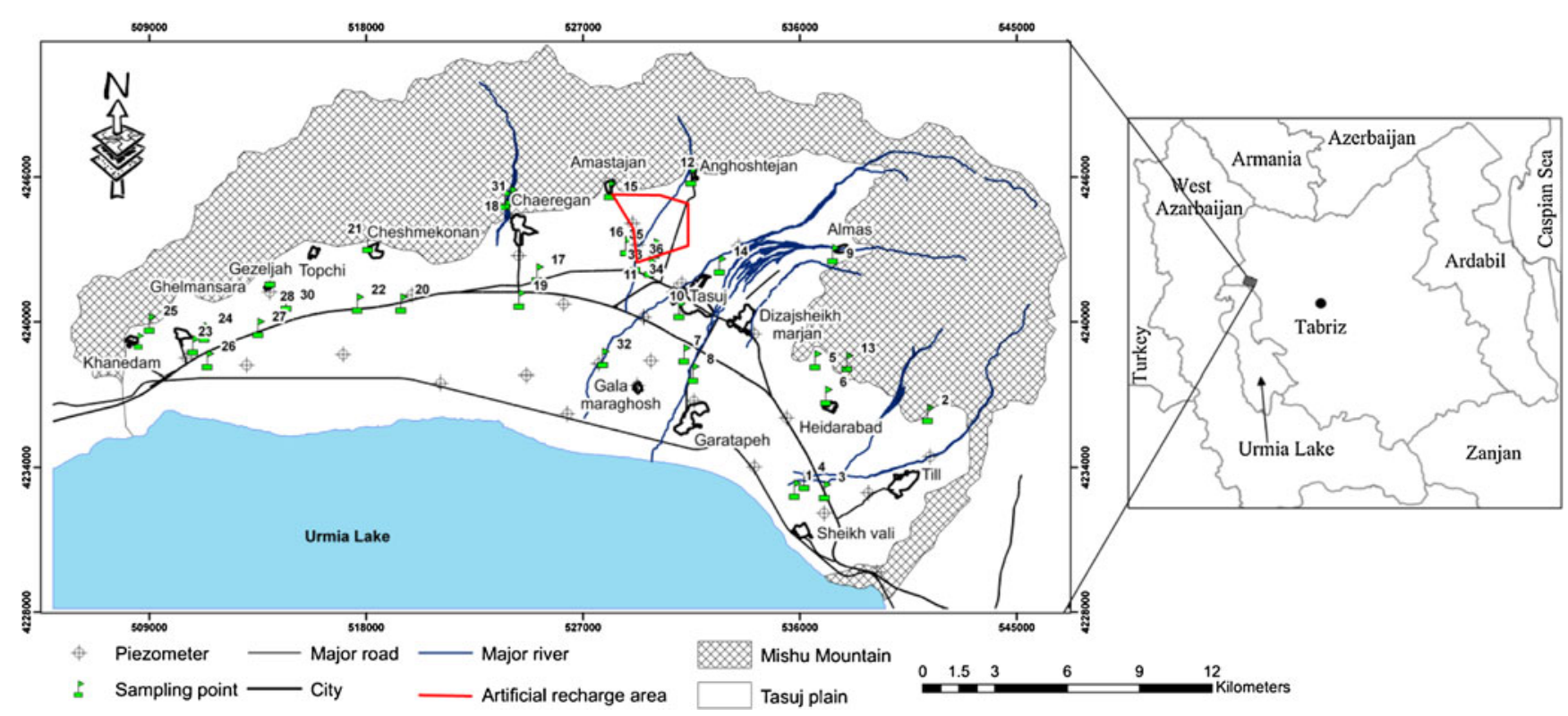

Figure 1. The study area and locations of sampling sites and piezometers.

$14^{\circ} \mathrm{C}$. In general, average monthly relative humidity at the Tasuj climatological station is fairly high ranging from 54\% (in July) to 68\% (in March).

In the Tasuj basin, only a few seasonal rivers originate from Mishu Mountain. These seasonal rivers can flood the Tasuj plain in the wet season. The seasonal rivers are the Amestejan, Angoshtejan, Almas, Chehregan, Tiran, Cheshmekonan, Sheikhvali, Sheikhmarjan and Ghelmansara. Currently, there are no hydrometric station in these rivers; therefore, their flow rates are unknown. By using the correlation between the plain and the flow rate of the rivers in nearby plains such as Shabestar, annual flow rate for the seasonal rivers in the Tasuj plain was estimated at about 64.16 million cubic meters per year (East Azerbaijan Regional Water Authority 2001).

The Tasuj plain includes an artificial groundwater recharge area located about $5 \mathrm{~km}$ north of the city of Tasuj and between the Amastejan and Angoshtejan villages (see figure 1). Rainwater is transmitted by Amestejan River and the Angoshtejan River from Mishu Mountain to the downstream retention pool and then delivered to the recharge area that contains terraces of high hydraulic conductivity. In the later analysis, we will discuss how the recharge water impacts on the hydrochemistry of groundwater in the Tasuj plain aquifer.

\subsection{Geological condition}

The Tasuj basin has geological formations from the Precambrian to the Quaternary age. The geological map is shown in figure 2. Precambrian formations include metamorphic complex and Kahar formation which are located in Mishu Mountain, northwest of the basin. The Kahar formation is mainly composed of shale, shale-sandstone and sandstone, which were slightly metamorphosed and changed to slate, quartzic slate and rarely phyllite. Paleozoic formations include Barut, Mila (Cambrian), Doroud and Ruteh (Permian) formations. Mesozoic sediments are limited to upper Triassic and Cretaceous deposits, which are at the north of Till village.

Marine deposits of Oligo-Miocene age are adversely developed in the study area. These rocks are red conglomerate, white-to-yellowish and pink limestone, red sandstone, shale and green marl. There are gypsiferous layers in the most of the lower Miocene formation. Therefore, OligoMiocene formation could have a significant effect on the hydrogeochemistry of the Tasuj plain aquifer.

Quaternary deposits are well developed in the basin. Travertine, tens of meters in thickness, occurs in the north of the Heidarabad and Till villages, which originated from springs through the geological faults (Khodabandeh and AminiFazl 1993). Alluvial deposits include old and young deposits. A mixture of both old and young deposits formed the alluvial plain and cultivated areas. Quaternary deposits near Urmia Lake change to salt flat. This area was formed due to Urmia Lake regression (Stocklin 1974; Berberian and King 1981).

There are several faults in the Tasuj basin shown in figure 2 (Stocklin 1968). The most important 


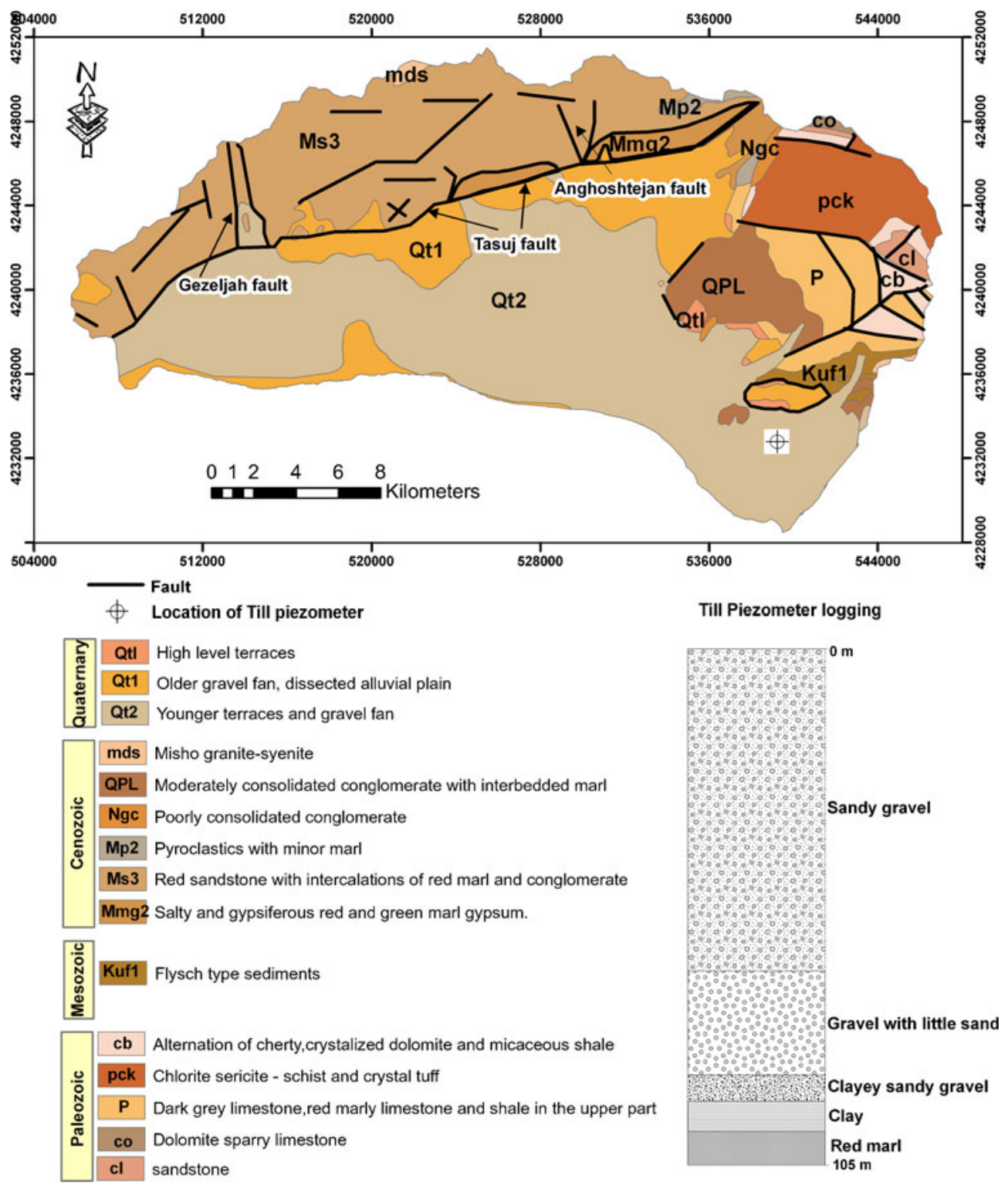

Figure 2. Geological map and Till piezometer logging (modified from Khodabandeh and Amini-Fazl 1993).

faults include the Tasuj fault, the Gzeljeh fault and the Angoshtejan fault. The Tasuj fault is a long, deep, and active reverse fault, extending from northeast to southwest. The north-south trending Gzeljeh and Angoshtejan faults are the important faults to the area. The Gzeljeh fault cuts the moderately consolidated conglomerate and sandstone unit and probably has a dominant role in the recharge of the Tasuj plain aquifer.

\subsection{Hydrogeology of the Tasuj plain aquifer}

The Tasuj plain aquifer is a heterogeneous unconfined aquifer. The aquifer system can be categorized into three groups based on hydraulic conductivity (East Azerbaijan Regional Water Authority 2001):

- the low hydraulic conductivity group: This group is composed of old and fine granular sedimentary,

- the intermediate hydraulic conductivity group: This group is composed of carbonate sedimentary and old alluvial terrace, and

- the high hydraulic conductivity group: This group includes young terrace, which is the main material of the aquifer. Erosion of old formation caused to form this young terrace.

Groundwater in the Tasuj plain aquifer was withdrawn through 147 water wells, 70 springs and 70 qanats. In 2009, groundwater was withdrawn 36.81 million cubic meters (East Azerbaijan 


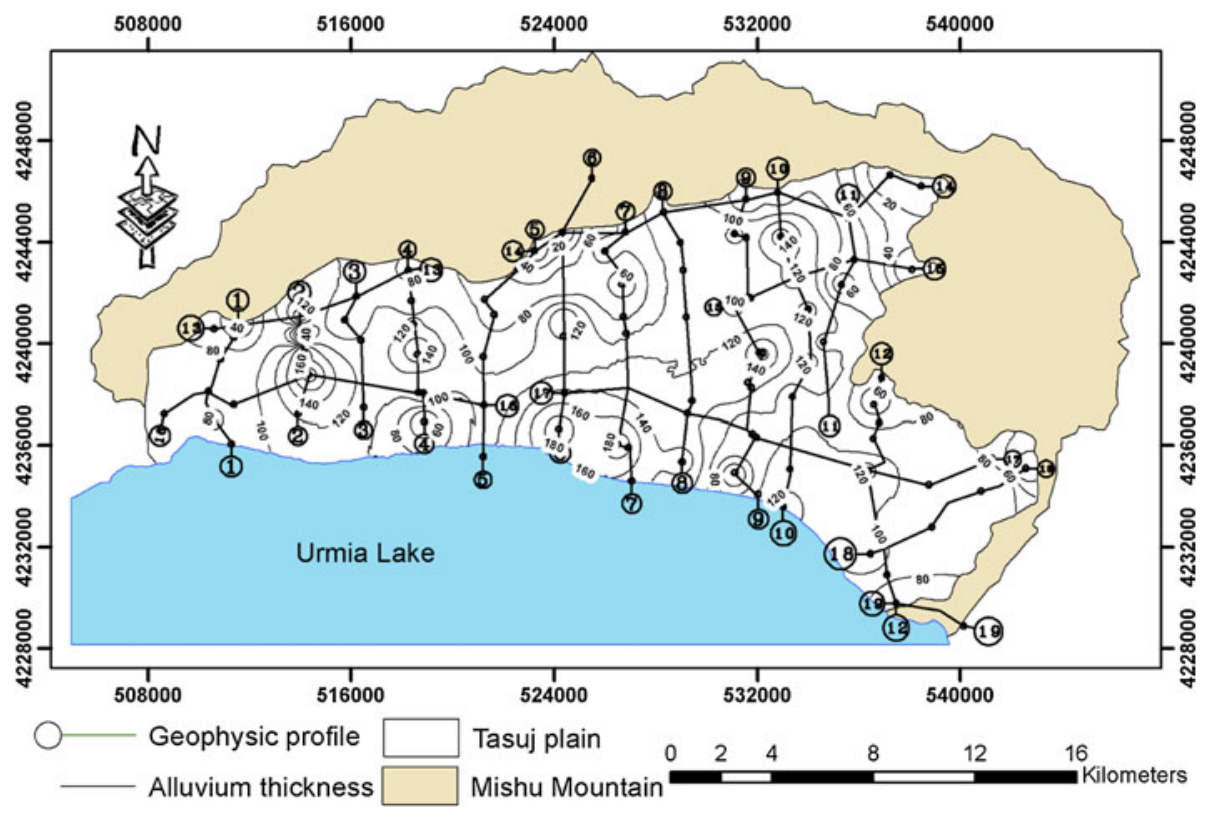

Figure 3. Thickness of Tasuj aquifer and location of profiles of geo-electrical survey.

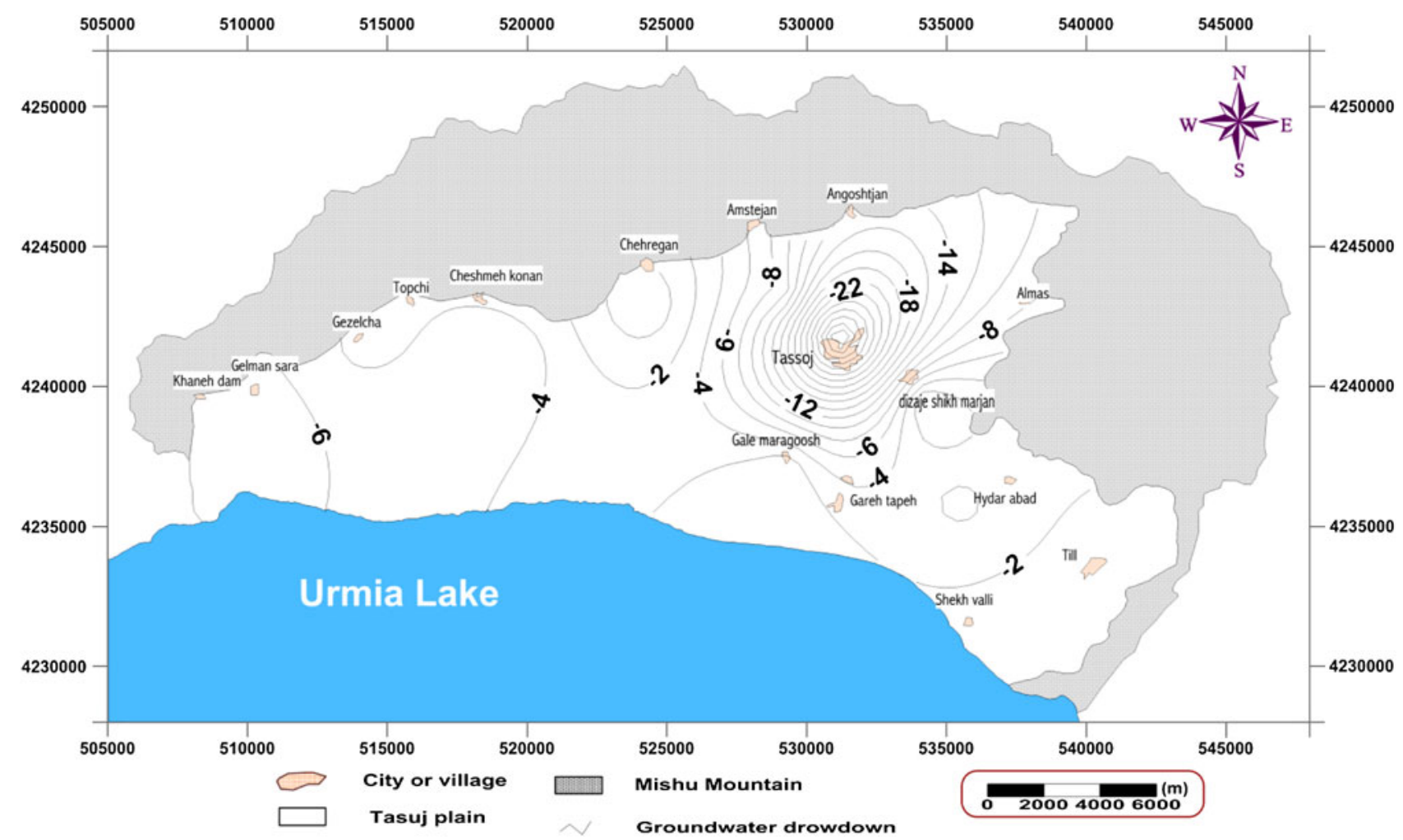

Figure 4. Difference of groundwater table (m) between 1999 and 2009.

Regional Water Authority 2010). Despite enacting restrictive rules such as limiting drilling new pumping wells and reducing pumping rate, 24 springs and 14 qanats became dry in the recent years due to over-extraction.

The geo-electrical survey shown in figure 3 was conducted in the plain by the Abkav Consulting
Engineering Co. (1973) to delineate thickness of the Tasuj plain aquifer. It was found that the bedrock of the plain is the Miocene formation, which generally dips south to Urmia Lake. The alluvial aquifer is thick along the profiles 2, 4, 5, and 7. The aquifer thickness decreases towards Urmia Lake. 
Based on seven pumping tests carried out in the plain by the East Azerbaijan Regional Water Authority (2001), the Till village, the city of Tasuj, and alluvial terraces have high transmissivity (150$\left.300 \mathrm{~m}^{2} / \mathrm{d}\right)$. Low transmissivity zone $\left(25-50 \mathrm{~m}^{2} / \mathrm{d}\right)$ is in the southwest of the plain due to thin aquifer thickness.

\subsection{Groundwater monitoring network}

Thirty piezometers were installed in the Tasuj plain to monitor groundwater level. Their locations are distributed over the entire region shown in figure 1. Groundwater level was recorded by East Azerbaijan Regional Water Authority from 1999 until 2009. We also collected groundwater level data from the Cheshmekonam piezometer from 1993 to the present.

Groundwater level discernibly declined in the last decade. The declination between the dry seasons of 1999 and 2009 is shown in figure 4. Due to the agricultural, industrial and drinking water demands, high withdrawal rates around the city of Tasuj produced the maximum cone of depression in this area. The maximum groundwater level decline rate was $3.7 \mathrm{~m}$ per year recorded in the Cheshmekonan piezometer. The maximum seasonal variation was observed from October (the lowest groundwater level) at the end of the irrigation season to June (the highest groundwater level). Figure 5 shows the
2009 groundwater level distribution. Groundwater flow direction in the Tasuj plain aquifer is mainly towards Urmia Lake.

\section{Methodology}

\subsection{Hydrochemical dataset}

We obtained 504 groundwater samples from 33 different water wells, springs and qanats between 1997 and 2009 and used them to characterize the hydrogeochemistry of the Tasuj plain aquifer. The maximum number of samples is 97 in 2004 and the minimum number of samples is 15 in 1997 . The location of the sample sites is shown in figure 1 . The samples were analyzed in the hydrogeological laboratory of University of Tabriz and in the laboratory of East Azerbaijan Regional Water Authority. The water quality parameters of interest were $\mathrm{Ca}^{2+}, \mathrm{Mg}^{2+}, \mathrm{Na}^{+}, \mathrm{K}^{+}, \mathrm{HCO}_{3}^{-}, \mathrm{CO}_{3}^{2-}$, $\mathrm{SO}_{4}^{2-}, \mathrm{Cl}^{-}$and $\mathrm{NO}_{3}^{-}$, which were determined by the standard methods (American Public Health Association 1998). Only samples in 2004 were analyzed for $\mathrm{NO}_{3}^{-}$. Moreover, $\mathrm{pH}$, electric conductivity (EC), and the total dissolved solid (TDS) were measured from the samples. Total hardness (TH), sodium absorption ratio (SAR), and sodium percent $(\mathrm{Na} \%)$ were calculated from the measured chemical parameters.

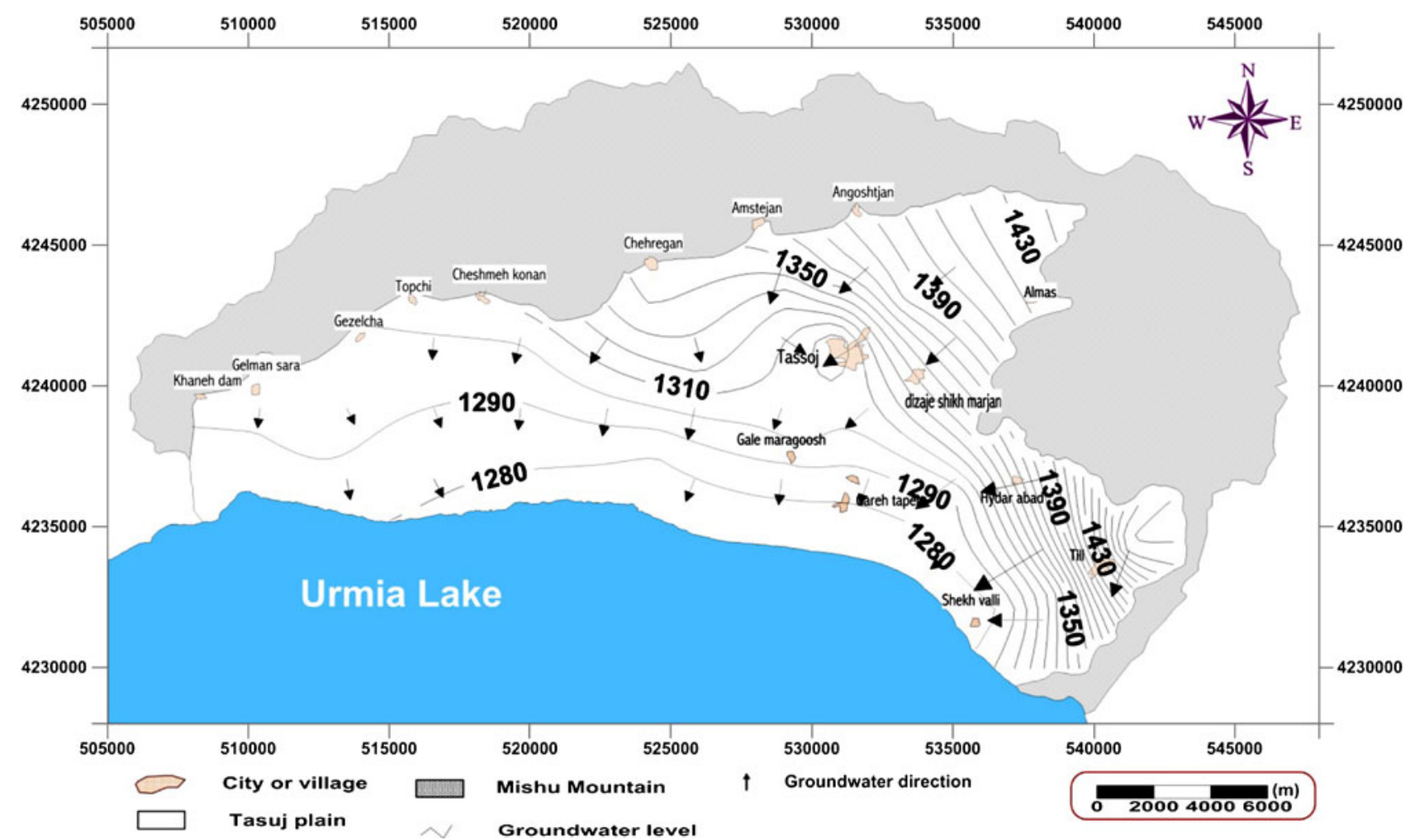

Figure 5. Groundwater level and flow direction (June 2009). 
Analysis accuracy was checked for charge balance for the water samples based on Hounslow (1995). The charge balance values for all the samples were $<5 \%$. Therefore, the analysis results were reliable.

Table 1 presents the statistics of the chemical constituents in the water samples which only the nitrate and sulfate concentrations found in this study exceed the maximum allowable concentration defined by U.S. National Primary and Secondary Drinking Water Regularizations (USEPA 2001), $10 \mathrm{mg} / \mathrm{L}$ (0.16 meq/L) and $250 \mathrm{mg} / \mathrm{L}$ (5.2 meq/L), respectively. This may be due to intensive agricultural activities in the study area.
The correlation matrix of hydrogeochemical parameters is shown in table 2. Significance level of entire parameters is smaller than $5 \%$, so the null hypothesis is rejected. Sulfate has a high positive correlation with chloride, sodium, and potassium and has a low positive correlation with calcium and magnesium. This implies that one of the sources of sulfate is sodium sulfate which was formed in the closed basin (Hem 1986), such as Urmia Lake Basin. High positive correlation of chloride with sodium and potassium implies that the main source of chloride is from halite and sylvite. High positive correlation of bicarbonate with calcium and magnesium implies that one

Table 1. Statistics for the 504 groundwater samples.

\begin{tabular}{|c|c|c|c|c|c|c|c|c|c|}
\hline Parameter & Unit & Minimum & Maximum & Mean & Median & Mode & Std. deviation & Skewness & Kurtosis \\
\hline $\mathrm{SO}_{4}^{-2}$ & meq/L & 0.06 & 15.38 & 3.36 & 2.70 & 2.00 & 2.28 & 1.06 & 1.65 \\
\hline $\mathrm{Cl}^{-}$ & $\mathrm{meq} / \mathrm{L}$ & 0.40 & 117.00 & 6.33 & 3.30 & 2.50 & 8.94 & 5.42 & 53.84 \\
\hline $\mathrm{HCO}_{3}^{-}$ & meq/L & 1.09 & 40.48 & 5.67 & 4.00 & 3.00 & 4.39 & 2.80 & 12.65 \\
\hline $\mathrm{CO}_{3}^{-2}$ & meq/L & 0.00 & 0.50 & 0.03 & 0.00 & 0.00 & 0.10 & 3.04 & 8.71 \\
\hline $\mathrm{NO}_{3}^{-}$ & $\mathrm{meq} / \mathrm{L}$ & 0.00 & 0.54 & 0.11 & 0.07 & 0.03 & 0.11 & 1.83 & 4.09 \\
\hline $\mathrm{K}^{+}{ }^{3}$ & meq/L & 0.00 & 0.90 & 0.19 & 0.13 & 0.09 & 0.16 & 1.69 & 3.29 \\
\hline $\mathrm{Na}^{+}$ & meq/L & 0.54 & 31.65 & 6.12 & 4.15 & 3.80 & 6.17 & 1.92 & 2.97 \\
\hline $\mathrm{Mg}^{+2}$ & meq/L & 0.88 & 21.58 & 4.15 & 3.50 & 2.00 & 2.47 & 2.47 & 10.96 \\
\hline $\mathrm{Ca}^{+2}$ & meq/L & 0.32 & 20.05 & 4.73 & 3.97 & 4.00 & 2.76 & 2.14 & 6.31 \\
\hline $\mathrm{pH}$ & - & 4.65 & 8.70 & 7.54 & 7.60 & 7.80 & 0.55 & -1.26 & 3.90 \\
\hline TDS & $\mathrm{mg} / \mathrm{L}$ & 192 & 3432.00 & 924.20 & 793.15 & 385.00 & 536.14 & 1.37 & 2.07 \\
\hline $\mathrm{TH}$ & meq/L & 8.63 & 1170.00 & 343.82 & 314.00 & 310.00 & 223.22 & 0.64 & 0.57 \\
\hline SAR & - & 0.24 & 16.90 & 2.89 & 2.19 & 2.10 & 2.56 & 1.90 & 3.75 \\
\hline $\mathrm{EC}$ & $\mu \mathrm{moh} / \mathrm{cm}$ & 320 & 5720 & 1486.98 & 1250.00 & 1300.00 & 870.25 & 1.44 & 2.36 \\
\hline$\% \mathrm{Na}$ & - & 7.00 & 73.21 & 36.37 & 36.10 & 44.00 & 15.89 & 0.41 & -0.66 \\
\hline
\end{tabular}

Table 2. Correlation matrix between chemicals for the groundwater samples.

\begin{tabular}{|c|c|c|c|c|c|c|c|c|c|c|c|c|c|c|c|}
\hline Parameter & $\mathrm{SO}_{4}^{-2}$ & $\mathrm{Cl}^{-}$ & $\mathrm{HCO}_{3}^{-}$ & $\mathrm{CO}_{3}^{-2}$ & $\mathrm{NO}_{3}^{-}$ & $\mathrm{K}^{+}$ & $\mathrm{Na}^{+}$ & $\mathrm{Mg}^{+2}$ & $\mathrm{Ca}^{+2}$ & $\mathrm{pH}$ & TDS & $\mathrm{TH}$ & SAR & $\mathrm{EC}$ & $\% \mathrm{Na}$ \\
\hline $\mathrm{SO}_{4}^{-2}$ & 1.00 & & & & & & & & & & & & & & \\
\hline $\mathrm{Cl}^{-}$ & 0.64 & 1.00 & & & & & & & & & & & & & \\
\hline $\mathrm{HCO}_{3}^{-}$ & -0.23 & -0.16 & 1.00 & & & & & & & & & & & & \\
\hline $\mathrm{CO}_{3}^{-2}$ & 0.04 & -0.10 & -0.18 & 1.00 & & & & & & & & & & & \\
\hline $\mathrm{NO}_{3}^{-}$ & -0.03 & 0.01 & -0.17 & -0.12 & 1.00 & & & & & & & & & & \\
\hline $\mathrm{K}^{+}$ & 0.57 & 0.69 & -0.20 & -0.04 & 0.20 & 1.00 & & & & & & & & & \\
\hline $\mathrm{Na}^{+}$ & 0.69 & 0.97 & -0.18 & -0.08 & 0.02 & 0.72 & 1.00 & & & & & & & & \\
\hline $\mathrm{Mg}^{+2}$ & 0.26 & 0.38 & 0.73 & -0.14 & -0.10 & 0.13 & 0.32 & 1.00 & & & & & & & \\
\hline $\mathrm{Ca}^{+2}$ & 0.33 & 0.41 & 0.68 & -0.19 & -0.14 & 0.25 & 0.35 & 0.71 & 1.00 & & & & & & \\
\hline $\mathrm{pH}$ & 0.12 & 0.01 & -0.70 & 0.46 & 0.17 & 0.12 & 0.04 & -0.55 & -0.56 & 1.00 & & & & & \\
\hline TDS & 0.62 & 0.89 & 0.22 & -0.14 & -0.04 & 0.59 & 0.88 & 0.66 & 0.65 & -0.25 & 1.00 & & & & \\
\hline $\mathrm{TH}$ & -0.01 & 0.27 & 0.24 & -0.09 & -0.15 & 0.03 & 0.23 & 0.38 & 0.25 & -0.16 & 0.42 & 1.00 & & & \\
\hline SAR & 0.60 & 0.85 & -0.30 & -0.04 & 0.03 & 0.68 & 0.93 & 0.10 & 0.11 & 0.16 & 0.73 & 0.23 & 1.00 & & \\
\hline $\mathrm{EC}$ & 0.64 & 0.91 & 0.22 & -0.14 & -0.04 & 0.62 & 0.90 & 0.67 & 0.67 & -0.25 & 0.98 & 0.40 & 0.74 & 1.00 & \\
\hline$\% \mathrm{Na}$ & 0.62 & 0.72 & -0.46 & 0.05 & 0.10 & 0.62 & 0.81 & -0.07 & -0.08 & 0.32 & 0.55 & 0.08 & 0.91 & 0.56 & 1.00 \\
\hline
\end{tabular}


of groundwater origins may be from calcite and dolomite. High negative correlation of bicarbonate with $\mathrm{pH}$ shows the hydrogeochemical process that increase in $\mathrm{pH}(>8.3)$ causes to vanish bicarbonate and to appear carbonate in the system.

\subsection{Methods for data analysis}

The multivariate statistical techniques such as hierarchical cluster analysis (HCA), factor analysis (FA), and discriminant analysis (DA) have been widely used as unbiased methods in analyzing groundwater quality data to draw meaningful information (Helena et al. 2000; Dragon 2006). The HCA, FA and DA techniques and the methodology used for their application are described in detail in many studies (Davis 1986; Guler et al. 2002; Lambrakis et al. 2004; Chen et al. 2007). In this section, we analyzed 15 hydrochemical parameters in table 1 and standardized them to ensure that each variable is weighed equally. The multivariate methods were adopted by using SPSS (SPSS Inc. 2008) and Statistica (StatSoft Inc. 2004).

In this study, the graphical methods (Piper diagram, Stiff diagram and Durov diagram), were also applied in addition to multivariate statistical analysis. For determining groundwater types and origins as well as visualizing the evolution of groundwater chemistry, Piper trilinear diagrams, Stiff pattern diagram and Durov diagram were adopted. For the graphical analysis, the concentration unit of the different constituents was converted to meq/L to be able to combine their ions (Hounslow 1995).

\section{Results and discussion}

\subsection{Hydrogeochemical analysis on samples in dry season, 2004}

In this study, we adopted the graphical methods and the multivariate statistical methods to analyze the sample data for the dry season, 2004.

\subsubsection{Graphical analysis}

Hydrogeochemical types of groundwater from pumping wells, springs, and qanats are indicated in the Piper diagram shown in figure 6 . The diamond plot is divided into five zones (A, B, C, D and $\mathrm{E}$ ) in order to distinguish different types of groundwater. In zones $\mathrm{A}, \mathrm{B}, \mathrm{C}$, and $\mathrm{D}$, two groups of anions and cations are dominant. For example, $\mathrm{SO}_{4}^{2-}-\mathrm{Cl}^{-}$anions and $\mathrm{Ca}^{2+}-\mathrm{Mg}^{2+}$ cations are dominant in zone $\mathrm{A}, \mathrm{HCO}_{3}^{-}-\mathrm{CO}_{3}^{2-}$ anions and $\mathrm{Ca}^{2+}$ $\mathrm{Mg}^{2+}$ cations are dominant in zone $\mathrm{B}$, and so forth. Zone E represents a mixing zone, where neither anions nor cations are dominant (Todd and Mays 2005).

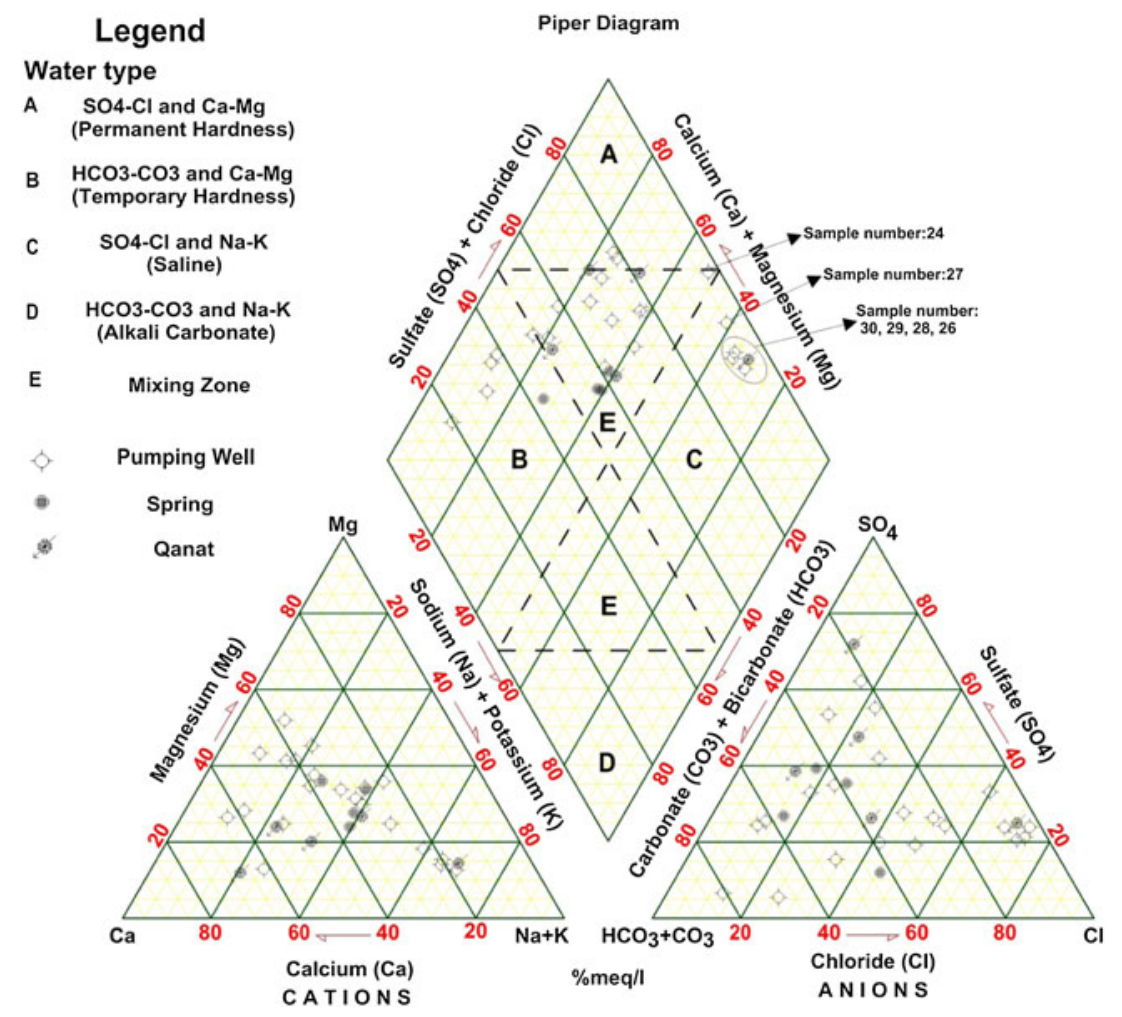

Figure 6. Piper diagram for dry season, 2004. 
Most of the groundwater samples are in zone E, where we cannot identify types of groundwater. A few samples are in zones A, B, and C. Samples in zone B indicate groundwater from formations that are composed of limestone and dolostone or from active recharge zones with short residence time (Hounslow 1995). The five samples in zone C may have originated from either halite dissolution or inverse ion exchange (Davis and Dewiest 1966). From hydrogeochemistry, it is understood that $\mathrm{Na}^{+} /\left(\mathrm{Na}^{+}+\mathrm{Cl}^{-}\right)<0.5$ indicates that the water is derived from inverse ion exchange (Hounslow 1995) and $\mathrm{Na}^{+} /\left(\mathrm{Na}^{+}+\mathrm{Cl}^{-}\right)=0.5$ indicates that water may be derived from halite dissolution. Therefore, samples 26, 28, 29, and 30 in $\mathrm{C}$ zone with $\mathrm{Na}^{+} /\left(\mathrm{Na}^{+}+\mathrm{Cl}^{-}\right)=0.5$ imply the source of water originated from halite dissolution. Sample 27 in zone $\mathrm{C}$ originated from inverse ion exchange. Sample 24 is located at the corner of zone E, which is different from other samples in the mixing zone and can be influenced by inverse ion exchange or shale (Hounslow 1995). Two samples in zone A are due to dissolution of gypsum. Halite, gypsum and shale originated from the Oligo-Miocene formation with bearing shale, halite, marl and gypsiferous strata.

Groundwater samples of the Tasuj plain were plotted into the expanded Durov diagram shown in figure 7 for hydrogeochemical process analysis. Based on Lloyd (1965), samples in fields 1 and 2 with dominant $\mathrm{HCO}_{3}^{-}-\mathrm{CO}_{3}^{2-}$ and $\mathrm{Ca}^{2+}-\mathrm{Mg}^{2+}$ indicate recharge area waters or waters originating from limestone and dolostone. They coincide with zone B in the Piper diagram in figure 6. Samples in the fifth field indicate that waters exhibit simple dissolution or mixing. It is consistent with the

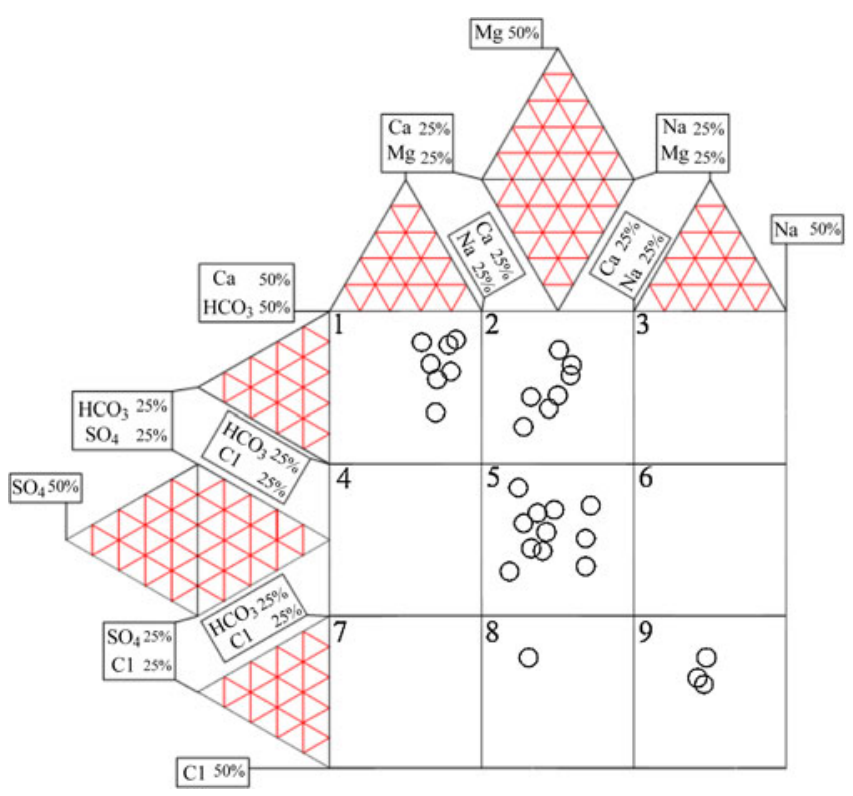

Figure 7. Expanded Durov diagram for dry season, 2004.

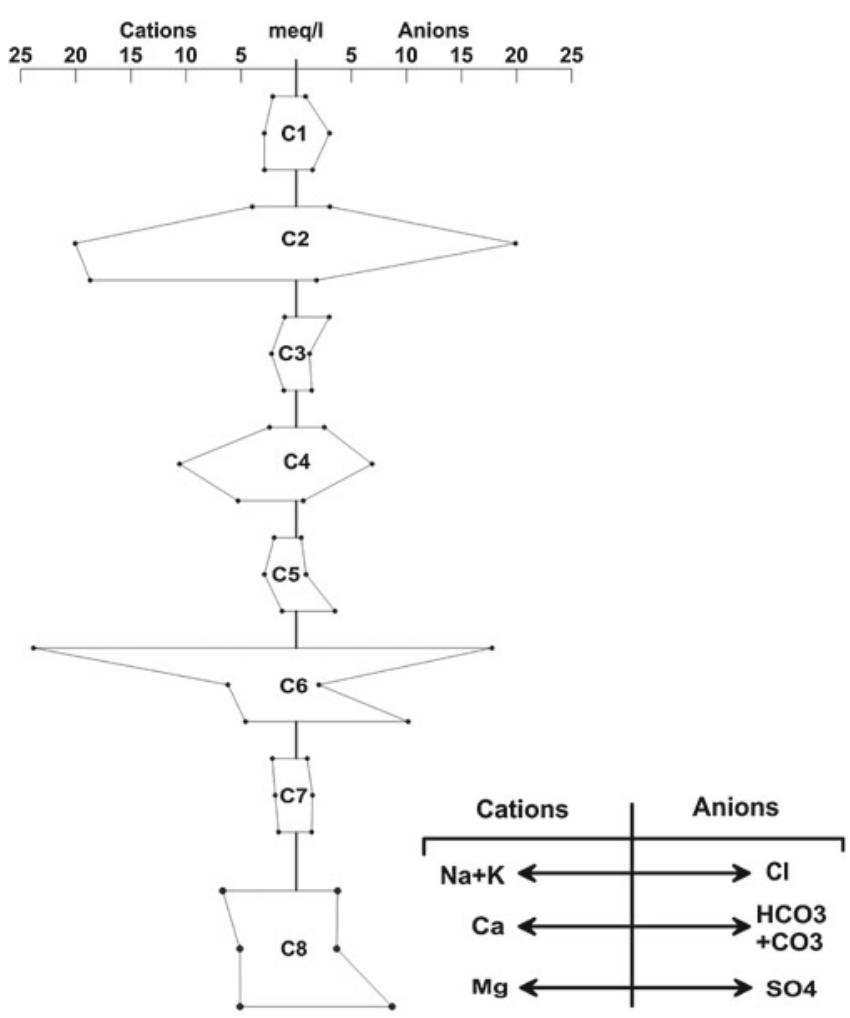

Figure 8. Stiff diagrams for dry season, 2004.

mixing zone (no dominant anions and cations) in the Piper diagram. Groundwater samples in field 8 are $\mathrm{Cl}^{-}$dominant and have non-dominant cations which may reflect inverse ion exchange of $\mathrm{Na}^{+}$ $\mathrm{Cl}^{-}$waters. Three samples in field 9 , where $\mathrm{Na}^{+}$ and $\mathrm{Cl}^{-}$are dominant, represents endpoint water (Zaporozec 1972; Lloyd and Heathcote 1985). It is consistent with samples in zone $\mathrm{C}$ in the Piper diagram.

We use a Stiff diagram to classify groundwater from different origins. As shown in figure 8, eight different origins were identified based on Hounslow (1995). We identify the origins of the water samples as follows. The $\mathrm{C} 1$ class indicates igneous rocks origin; the $\mathrm{C} 2$ class indicates groundwater with dolostone dominant origin; the $\mathrm{C} 3$ class shows inverse ion exchange process; the $\mathrm{C} 4$ class indicates groundwater with limestone dominant origin; the C5 class shows gypsiferous formation origin; the C6 indicates saline water; the $\mathrm{C} 7$ class shows mixing groundwater; and the $\mathrm{C} 8$ class shows groundwater that was influenced by ion exchange or originated from shale.

\subsubsection{Multivariate statistical analysis}

\subsubsection{Hierarchical cluster analysis}

Using hierarchical cluster analysis, the 30 groundwater samples in the dry season 2004 are shown in the dendrogram in figure 9 . In our study, we 


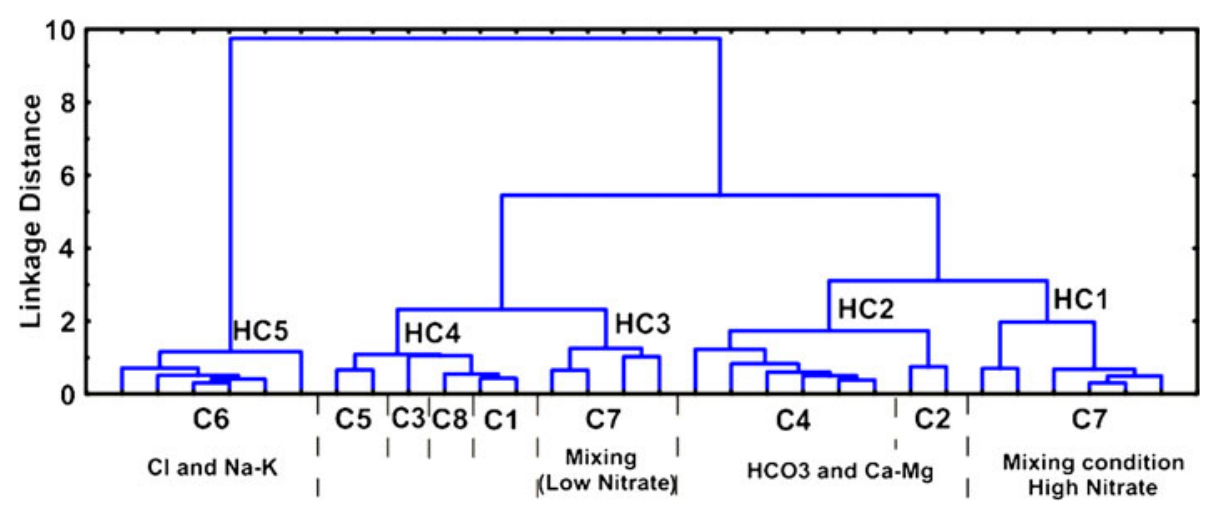

Figure 9. Five clusters in the dendrogram for the groundwater samples in dry season, 2004.

adopted the Euclidean distance as a distance measure (or similarity measurement) between samples and Ward's method as a linkage rule. The threshold for the linkage distance is set to 2.2. Samples with linkage distance shorter than 2.2 are grouped into the same cluster. This threshold results in five clusters, named from HC1 to HC5.

The dendrogram implies a level of hydrochemical similarity among the five clusters. HC3 and $\mathrm{HC} 4$ have similar linkage distance, and thus, have greater hydrogeochemical similarity. Hydrogeochemical similarity between the geochemistry of $\mathrm{HC} 1$ and $\mathrm{HC} 2$ samples are also strong. HC5 is hydrochemically distinct from other clusters since the HC5 samples are in zone $\mathrm{C}$ in the Piper diagram.

The hierarchical cluster analysis is able to show the influence of nitrate concentration in classification while the graphical methods cannot. Based on the nitrate concentration, the data in the mixing zone was classified into the $\mathrm{HC} 1$ and $\mathrm{HC} 3$ classes. According to the results of graphical methods, the samples of the $\mathrm{HC} 2$ class were influenced by the existence of limestone and dolomite formations. The mixing zone data in the $\mathrm{HC} 1$ and $\mathrm{HC} 3$ classes relates to the $\mathrm{HC} 2$ and $\mathrm{HC} 4$ classes, respectively. The existence of shale, sandstone, marl and gypsiferous strata may cause the appearance of the HC4 class.

\subsubsection{Discriminant analysis}

To verify if the aforementioned five groups were classified correctly by the cluster analysis technique, we applied the discriminant analysis (DA) to the hydrogeochemical data of the Tasuj plain aquifer. We found that the dependent variables consist of the classified groups of samples that resulted from the cluster analysis. Therefore, all the samples were classified to their correct groups, indicating the reliable results from the cluster analysis technique. We used the squared Mahalanobis distance shown in table 3 to discriminate the groups
Table 3. Squared Mahalanobis distances of groups.

\begin{tabular}{lccccc}
\hline Group & HC1 & HC2 & HC3 & HC4 & HC5 \\
\hline HC1 & 0 & & & & \\
HC2 & 22.9395 & 0 & & & \\
HC3 & 39.2391 & 41.6367 & 0 & & \\
HC4 & 49.0942 & 58.9392 & 22.1799 & 0 & \\
HC5 & 252.18 & 345.972 & 371.251 & 401.346 & 0 \\
\hline
\end{tabular}

and found that the HC5 class, which corresponds to $\mathrm{Na}^{+}-\mathrm{Cl}^{-}$, is apparently different from other four groups.

\subsubsection{Factor analysis}

We used factor analysis to find effective factors impacting on the hydrogeochemistry of the Tasuj plain and the significance of correlation between factors and variables of the data. Strong positive or negative correlation between a variable and a factor is indicated by a high factor loading close to 1 or -1 , respectively. Moreover, we adopted the varimax rotation technique (Kaiser 1958) to distinguish variables with high factor loadings (close to 1 or -1 ) from variables with low factor loadings (close to 0 ). Three factors were identified to interpret hydrochemical process in the Tasuj plain aquifer. They explained $81.6 \%$ of data variance. The results of factor analysis are presented in table 4. Factor 1 and factor 3 present the largest and smallest variances, respectively. Factor 1 explains $43.38 \%$ of total variance and shows high positive factor loadings for $\mathrm{SO}_{4}^{2-}, \mathrm{Cl}^{-}, \mathrm{Na}^{+}$, $\mathrm{K}^{+}$, TDS, SAR, EC, and Na\%. Factor 2 accounts for $30.17 \%$ of total variance and is characterized by high positive factor loadings of $\mathrm{TH}, \mathrm{Mg}^{2+}$, $\mathrm{Ca}^{2+}$ and $\mathrm{HCO}_{3}^{-}$. Factor 3 accounts for $8.03 \%$ of total variance and is characterized by high positive factor loadings of $\mathrm{NO}_{3}^{-}, \mathrm{pH}$, and $\mathrm{CO}_{3}^{2-}$.

High factor score of factor 1 is in the west and middle areas of the plain, which have low hydraulic conductivity due to fine grain sediment. These 
areas have long groundwater residence time and show the influence from salty, gypsiferous layers. High factor score of factor 2 is in the recharge areas, where the aquifers have high quality water. High factor score of factor 3 is in the areas with intensive agricultural activity and domestic sewage. The connectivity between the surface activities and the aquifer has led to the leaching of the nitrate from the anthropogenic activities into the aquifers. In the east of the plain, the high factor scores are associated with cattle ranging and intense application of nitrate-rich manures and chemical fertilizers.

High factor loadings of variables that reflect natural hydrogeochemical processes are grouped in factors 1 and 2 and named the geogenic factor. These variables show the influence of salty,

Table 4. Results of factor analysis.

\begin{tabular}{lccr}
\hline Variable & Factor 1 & Factor 2 & Factor 3 \\
\hline $\mathrm{SO}_{4}^{-2}$ & $0.80^{*}$ & 0.38 & 0.01 \\
$\mathrm{Cl}^{-}$ & $0.93^{*}$ & 0.22 & 0.00 \\
$\mathrm{HCO}_{3}^{-}$ & -0.39 & $0.83^{*}$ & 0.01 \\
$\mathrm{CO}_{3}^{-2}$ & -0.11 & -0.23 & $0.69^{*}$ \\
$\mathrm{NO}_{3}^{-}$ & 0.01 & -0.19 & $0.76^{*}$ \\
$\mathrm{~K}^{+}$ & $0.67^{*}$ & -0.03 & 0.36 \\
$\mathrm{Na}^{+}$ & $0.97^{*}$ & 0.14 & 0.02 \\
$\mathrm{Mg}^{+2}$ & 0.16 & $0.91^{*}$ & -0.03 \\
$\mathrm{Ca}^{+2}$ & 0.19 & $0.87^{*}$ & 0.03 \\
$\mathrm{pH}$ & 0.41 & -0.48 & $0.72^{*}$ \\
$\mathrm{TDS}$ & $0.69^{*}$ & 0.48 & 0.02 \\
$\mathrm{TH}$ & 0.19 & $0.97^{*}$ & -0.01 \\
$\mathrm{SAR}$ & $0.85^{*}$ & -0.29 & 0.04 \\
$\mathrm{EC}$ & $0.69^{*}$ & 0.48 & 0.02 \\
$\% \mathrm{Na}$ & $0.84^{*}$ & -0.42 & 0.06 \\
\hline
\end{tabular}

*Loading $>0.65$. gypsiferous, limestone formation and dolomitic formation. The most important geogenic factor is factor 1, which clearly describes the effect of geological formations on hydrochemical processes according to the increasing EC and TDS at the end of the groundwater flow path. High factor loadings of $\mathrm{CO}_{3}^{2-}$ and $\mathrm{NO}_{3}^{-}$may explain the effect of fertilizers (agricultural activity) and human activities in the Tasuj plain. This factor is associated with the influence of contamination from land surface and is, therefore, an anthropogenic factor.

According to the factor analysis results, we can assert that the main factor controlling hydrogeochemical processes in the study area is the geogenic factor that the geological formation has a high impact on quality of groundwater in the Tasuj plain aquifer.

\subsection{Temporal hydrogeochemical variations}

The annual average of EC from the samples may provide a general view of a temporal variation of groundwater quality in the aquifer. As shown in figure 10, from 1999 to 2009 the annual average EC increases when annual average precipitation decreases and vice versa in the Tasuj plain. In other words, the annual average precipitation controls the groundwater quality in the Tasuj plain. Increasing EC implies that the TDS increases, which in turn results in decreasing groundwater quality in the Tasuj plain.

To investigate the water quality variation in detail, we analyze additional data in 2000, 2003, 2006 and 2009 in addition to 2004. The results of hierarchical cluster analysis show that the number of groups is the same as 2004. Comparing the dendrograms from 2000 to 2009 in figures 9 and 11,

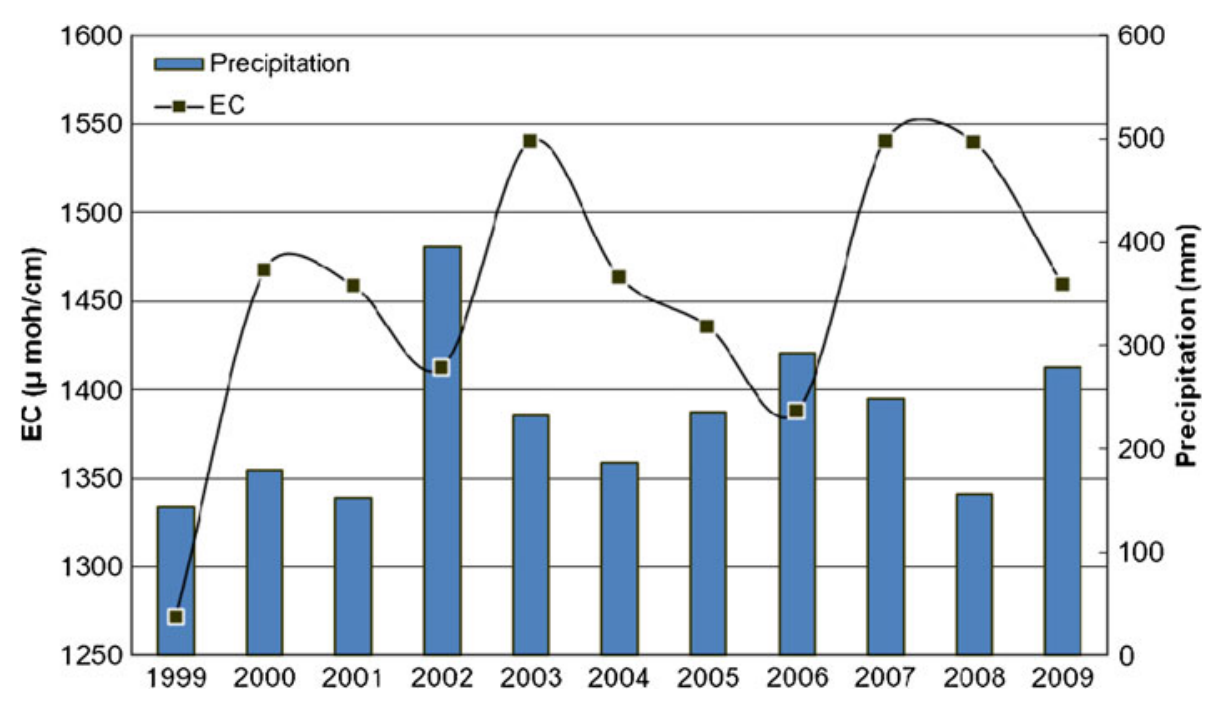

Figure 10. The annual average of EC and precipitation from 1999 to 2009. 


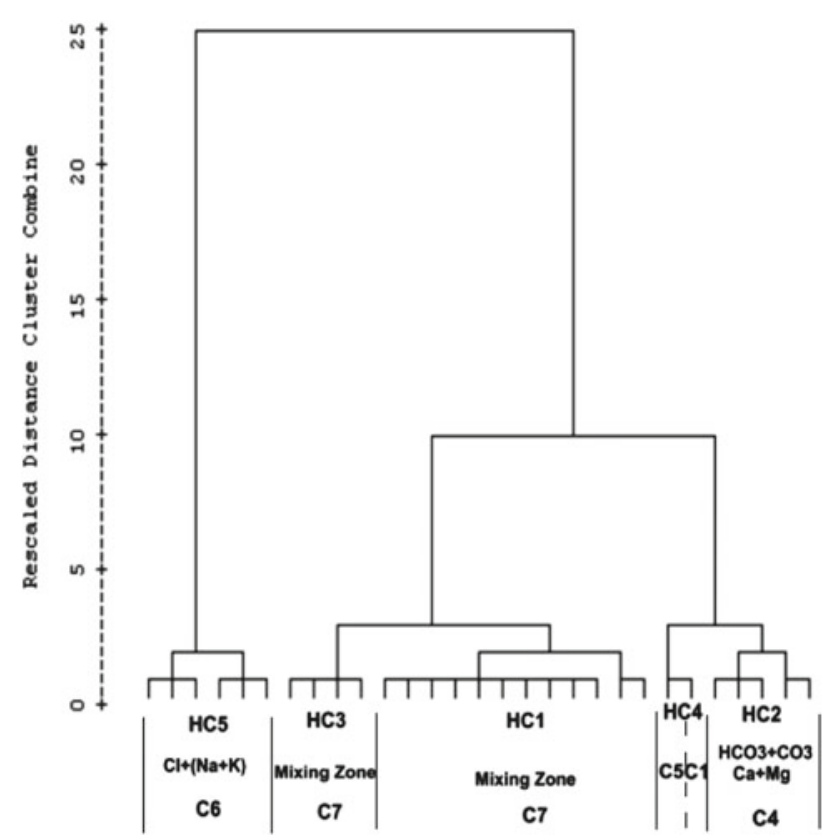

(a)

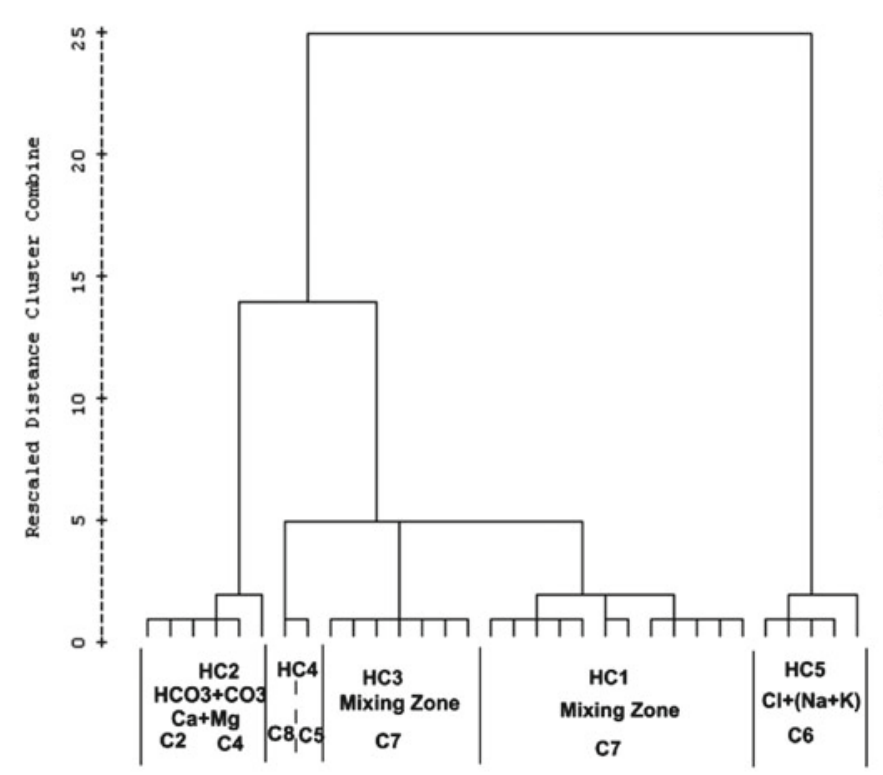

(c)

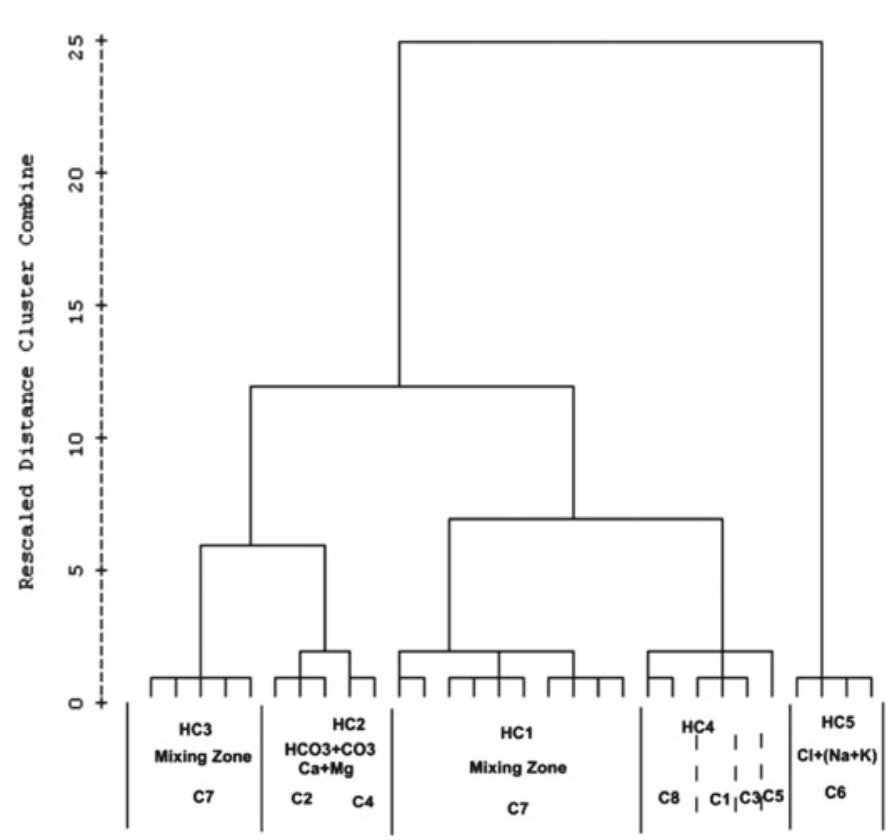

(b)

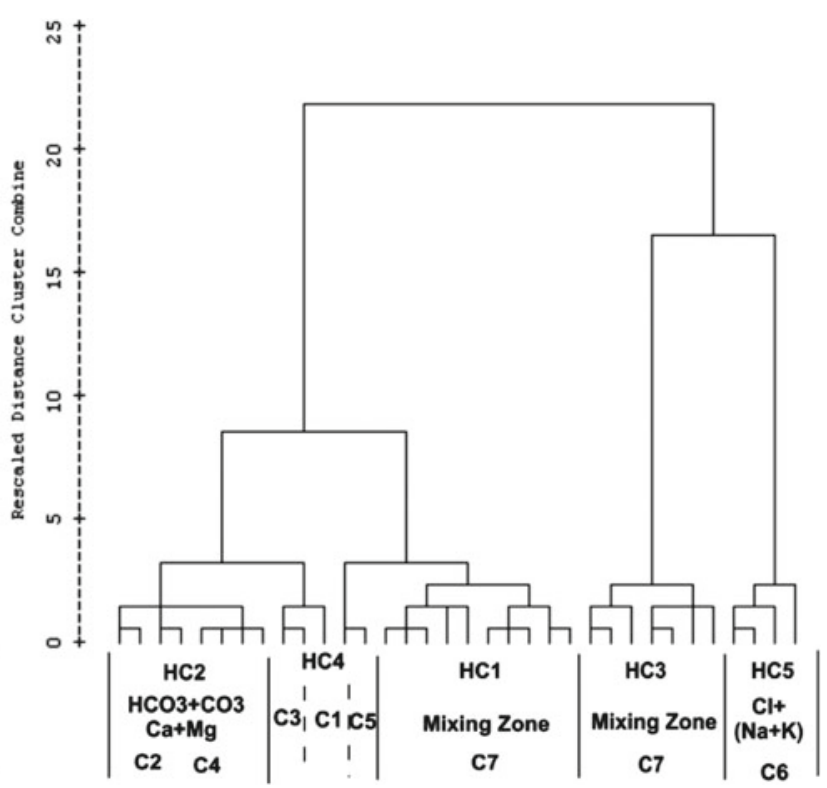

(d)

Figure 11. Dendrograms for (a) 2000, (b) 2003, (c) 2006, and (d) 2009.

the HC4 group varies significantly over time. In 2000, 2006, and 2009, the HC4 group has 2 classes (C1, C5), 2 classes (C5, C8), and 3 classes (C1, C3, C5), respectively. However, the $\mathrm{HC} 4$ group has 4 classes (C1, C3, C5, and C8) in 2003 and 2004. The appearance of these classes is mostly influenced by water and rock interaction through groundwater level variation, residence time, precipitation and drawdown. The HC5 group, which corresponds to $\mathrm{Na}^{+}-\mathrm{Cl}^{-}$type, has much higher linkage distance than other groups. However, the linkage distance of
HC5 with respect to other groups decreased from 2000 to 2009. In 2009, the HC5 group is very close to the HC3 (mixing zone) group.

Based on the four types of groundwater shown in the Piper diagram, we applied indicator kriging to obtain the distribution of groundwater types for 2000 and 2009 shown in figure 12 . We found that the mixing zone was extended in 2009. This may be due to artificial groundwater recharge mentioned in the previous section. Also, the $\mathrm{SO}_{4}^{2-}+\mathrm{Cl}^{-}-\left(\mathrm{Na}^{+}+\mathrm{K}^{+}\right)$water type in the 

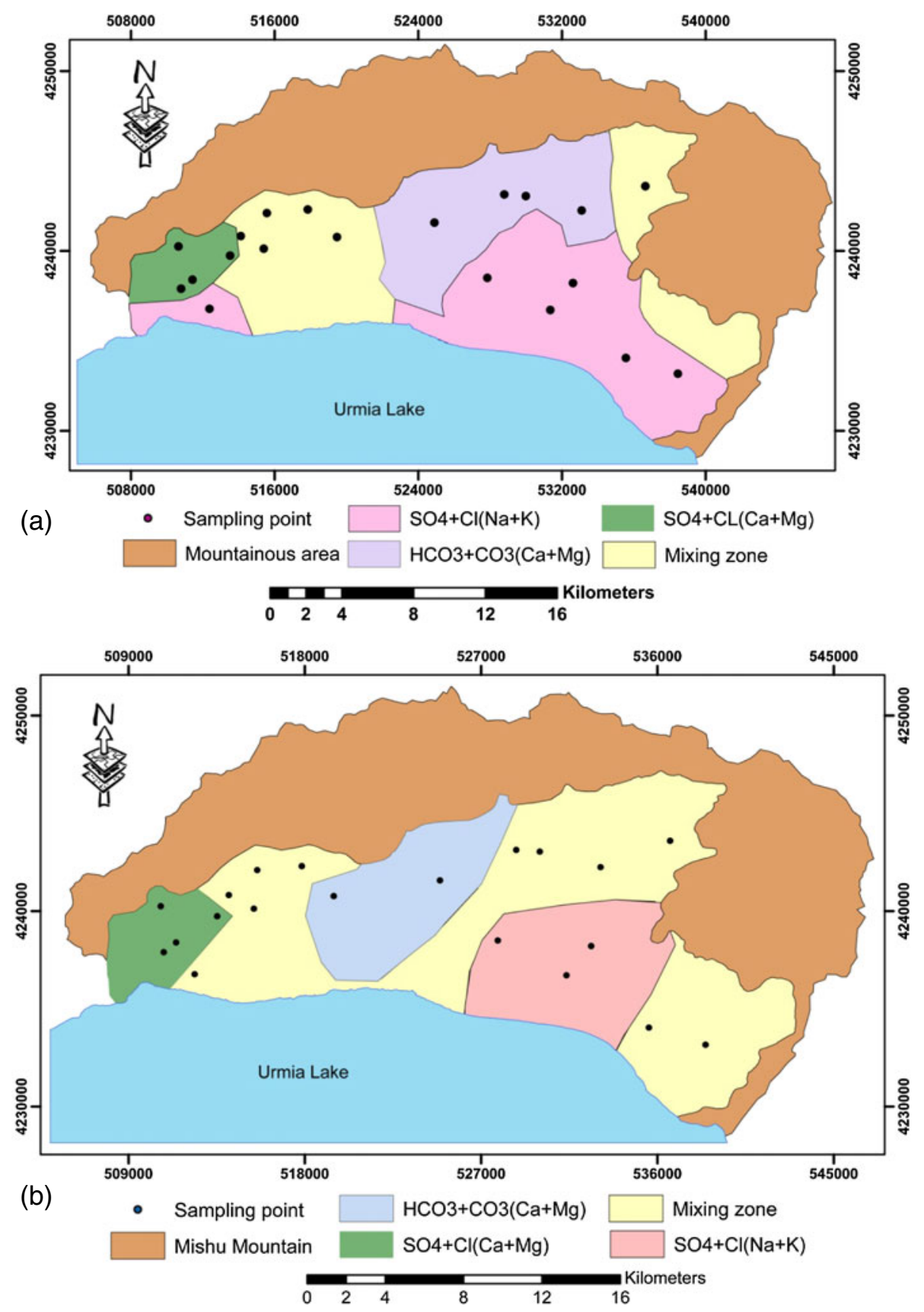

Figure 12. Groundwater type distribution (a) 2000 and (b) 2009.

west of the plain changed to $\mathrm{SO}_{4}^{2-}+\mathrm{Cl}^{-}-\left(\mathrm{Mg}^{2+}+\right.$ $\left.\mathrm{Ca}^{2+}\right)$. This may be the effect of inverse ion exchange due to fine grain sediment in that area.

\section{Conclusions}

Through the hydrogeological investigation, the study shows that the Tasuj plain aquifer is composed of alluvium which contained detrital material of different formations that includes igneous and metamorphic rock, dolostone, limestone, conglomerate, sandstone, and salty gypsiferous marl. The center of the plain near the city of Tasuj and the southeast of the plain have a thick alluvium. As a result, transmissivity is high $\left(150-300 \mathrm{~m}^{2} / \mathrm{d}\right)$ in these areas. However, thin aquifer thickness in the southwest of the plain as well as low permeability causes low transmissivity $\left(25-50 \mathrm{~m}^{2} / \mathrm{d}\right)$.

The graphical methods and multivariate analysis techniques were able to identify specific hydrogeochemical processes in the study area. Piper diagrams showed four types of groundwater quality 
and a Durov diagram deduced important hydrogeochemical processes (e.g., inverse ion exchange and mixing). Stiff diagrams classified hydrogeochemical data into eight classes and determined their origins.

However, hierarchical cluster analysis (HCA) clustered samples into five classes. By taking advantage of $\mathrm{HCA}$, we found that nitrate concentration (a minor ion) influences the mixing zone samples and the samples can be divided into two groups ( $\mathrm{HC} 1$ and $\mathrm{HC} 3$ ) with different nitrate concentrations. We used this advantage to identify high nitrate samples in the selected 4 years. Discriminant analysis (DA) method showed the consistency in using the HCA as a clustering method. Factor analysis (FA) deduced three effective factors for the hydrochemistry of the study area. Also, FA showed that the most important factor was geogenic factor which indicates high impact of geological formations. Nevertheless, the anthropogenic factor inferred the effect of agricultural activity and domestic sewage on groundwater quality of the Tasuj plain.

The temporal variation of groundwater quality was evaluated by the annual average EC from 1999 to 2009. We found that annual average EC in the Tasuj aquifer has high inverse correlation with annual average precipitation. Therefore, groundwater quality is controlled by annual average precipitation.

Comparison of the HCA results from dendrograms helped us to identify high nitrate sample group (HC1) based on sampling location. According to the distribution of different groundwater types, artificial recharge may have expanded the mixing zone. Also, $\mathrm{SO}_{4}^{2-}+\mathrm{Cl}^{-}-\left(\mathrm{Na}^{+}+\mathrm{K}^{+}\right)$water type in the west of the plain changed to $\mathrm{SO}_{4}^{2-}+\mathrm{Cl}^{-}-\left(\mathrm{Mg}^{2+}+\mathrm{Ca}^{2+}\right)$, which may be the effect of inverse ion exchange due to fine grain sediment in the west part of the Tasuj plain.

This study concludes that the graphical methods and the multivariate analysis methods are useful methods for the investigation of complex hydrogeochemical data. These methods can be useful for deduction of different hydrogeochemical processes and hydrogeochemical evolution and variation in a hydrogeological system.

\section{Acknowledgements}

This study was supported in part by the Research Office at University of Tabriz. The Iran Ministry of Science, Research and Technology provided scholarship to A A Nadiri and E Fijani to conduct research at Louisiana State University. The authors wish to acknowledge the East Azerbaijan Regional Water Authority for supplying data. Authors wish to thank M Oroji for his kind help during the laboratory works.

\section{References}

Abkav Consulting Engineering Co. 1973 Geophysical studies reports of Tabriz, Tasuj and Shabestar plains; East Azerbaijan Regional Water Authority (in Persian).

Adams S, Titus R, Pietersen K, Tredoux G and Harris C 2001 Hydrochemical characteristics of aquifers near Sutherland in the Western Karoo, South Africa; J. Hydrol. 241(1-2) 91-103.

Al-Shaibani A M 2008 Hydrogeology and hydrochemistry of a shallow alluvial aquifer, western Saudi Arabia; Hydrogeol. J. 16(1) 155-165.

American Public Health Association 1998 Standard Method for the Examination of Water and Wastewater; 17th edn (Washington, DC).

Asghari Moghaddam A and Fijani E 2008 Distribution of fluoride in groundwater of Maku area, northwest of Iran; J. Environ. Geol. 56(2) 281-287.

Asghari Moghaddam A and Fijani E 2009 Hydrogeologic framework of the Maku area basalts, northwestern Iran; Hydrogeol. J. 17(4) 949-959.

Berberian M and King G C P 1981 Towards the paleogeography and tectonic evolution of Iran; Canadian J. Earth Sci. 18(2) 210-265.

Chae G T, Kim K, Yun S-T, Kim Y-H, Kim S-O, Choi B-Y, Kim H-S and Rhee C W 2004 Hydrogeochemistry of alluvial groundwaters in an agricultural area: An implication for groundwater contamination susceptibility; Chemosphere 55(3) 369-378.

Chen K, Jiao J J, Huang J and Huang R 2007 Multivariate statistical evaluation of trace elements in groundwater in a coastal area in Shenzhen, China; Environ. Pollut. 147(3) 771-780.

Cloutier V, Lefebvre R, Therrien R and Savard M M 2008 Multivariate statistical analysis of geochemical data as indicative of the hydrogeochemical evolution of groundwater in a sedimentary rock aquifer system; J. Hydrol. 353(3-4) 294-313.

Dalton M G and Upchurch S G 1978 Interpretation of hydrochemical facies by factor analysis; Ground Water 16(4) $228-233$.

Davis J C 1986 Statistics and Data Analysis in Geology; New York, Wiley, 647p.

Davis S N and Dewiest R J M 1966 Hydrogeology; Krieger Publication Co., 476p.

de Martonne E 1925 Traité de Géographie Physique: 3 tomes, Paris.

Dragon K 2006 Application of factor analysis to study contamination of a semi-confined aquifer (Wielkopolska Buried Valley aquifer, Poland); J. Hydrol. 331(1-2) 272-279.

Durov S A 1948 Natural waters and graphic representation of their composition: Dokl; Akad. Nauk. SSSR 59 87-90.

East Azerbaijan Regional Water Authority 2001 Studying of groundwater resources and mathematical modeling of Tasuj Plain using GIS; Vol. I, p. 212 (in Persian).

East Azerbaijan Regional Water Authority 2010 Annual report of water balance of Tasuj plain (in Persian).

Emberger L 1930 Sur une formule applicable en géographie botanique; Cah. Herb. Seanc. Acad. Sci. 191 389-390.

Grande A, Gonzalez R, Beltran R and Sanchez-Rodas D 1996 Application of factor analysis to the study of contamination in the aquifer system of Ayamonte-Huelva (Spain); Ground Water 34(1) 155-161. 
Guler C, Thyne G D, McCray J E and Turner A K 2002 Evaluation of graphical and multivariate statistical methods for classification of water chemistry data; Hydrogeol. J. 10(4) 455-474.

Helena B, Pardo B, Vega M, Barrado E, Fernandez J M and Fernandez L 2000 Temporal evolution of groundwater composition in an alluvial aquifer (Pisuerga River, Spain) by principal component analysis; Water Research $\mathbf{3 4 ( 3 )}$ 807-816.

Hem J D 1986 Study and interpretation of the chemical characteristics of natural water; U.S. Geol. Survey Water-Supply Paper, 363p.

Hossain G, Howladar M F, Nessa L, Ahmed S S and Quamruzzaman C 2010 Hydrochemistry and classification of groundwater resources of Ishwardi Municipal Area, Pabna District, Bangladesh; Geotech. Geol. Eng. 28(5) 671-679.

Hounslow A W 1995 Water Quality Data: Analysis and interpretation; Lewis Publisher, 397p.

Jackson J E 1991 A User's Guide to Principal Components; Wiley, New York.

Jiang Y, Wue Y, Groves C, Yuan D and Kambesis P 2009 Natural and anthropogenic factors affecting the groundwater quality in the Nandong karst underground river system in Yunan, China; J. Cont. Hydrol. 109(1-4) 49-61.

Johnson R A and Wichern D W 1992 Applied Multivariate Statistical Analysis; Prentice-Hall International, Englewood Cliffs, NJ, USA, 642p.

Kaiser H F 1958 The Varimax criterion for analytic rotation in factor analysis; Psychometrika 23(3) 187-200.

Khazaei E, Stednick J D, Sanford W E and Warner J W 2006 Hydrochemical changes over time in the Zahedan aquifer, Iran; Environ. Monit. Assess. 114(1-3) 123-143.

Khodabandeh A A and Amini-Fazl A 1993 Geological map of Tasuj sheet (1:100,000); Geological Survey of Iran.

Laaksoharju M, Tullborg E-L, Wikberg P, Wallin B and Smellie J 1999 Hydrogeochemical conditions and evolution at the Äspö HRL, Sweden; Appl. Geochem. 14(7) 835-859.

Lambrakis N, Antonakos A and Panagopoulos G 2004 The use of multicomponent statistical analysis in hydrogeological environmental research; Water Res. 38(7) 1862-1872.

Lloyd I W 1965 The hydrochemistry of the aquifers of NorthEastern Jordan; J. Hydrol. 3(3-4) 319-330.

Lloyd J W and Heathcote J A 1985 Natural inorganic hydrochemistry in relation to groundwater - An introduction; Clarrendon Press, Oxford, 296p.
Matalas C N and Reiher J B 1967 Some comments on the use of factor analysis; Water Resour. Res. 3(1) 213-223.

Piper A M 1944 A graphical procedure in the geochemical interpretation of water analyses; Am. Geophys. 25 914-923.

Reghunath R, Murthy T R S and Raghavan B R 2002 The utility of multivariate statistical techniques in hydrogeochemical studies: An example from Karnataka, India; Water Res. 36(10) 2437-2442.

Research Center of Agriculture and Natural Resources of East Azerbaijan Province 2010.

Schwartz F W and Zhang H 2003 Fundamentals of Groundwater; John Wiley and Sons, 583p.

Singh P K, Malika A, Mohana D and Sinhab S 2004 Multivariate statistical techniques for the evaluation of spatial and temporal variations in water quality of Gomti River (India) - a case study; Water Res. 38(18) 3980-3992.

Singhal B B S and Gupta R P 1999 Applied Hydrogeology of Fractured Rocks; Kluwer Academic Publishers, Dordrecht, The Netherlands, 400p.

SPSS Inc. 2008 SPSS for windows, Version 17.

StatSoft Inc. 2004 Statistica (Data Analysis Software System), Version 6.

Stiff H A 1951 The interpretation of chemical water analysis by means of patterns; J. Petrol. Technol. 3(10) 60-62.

Stocklin J 1968 Structural history and tectonics of Iran: A review; Am. Assoc. Petrol. Geol. 52(7) 1229-1258.

Stocklin J 1974 Possible ancient continental margins in Iran; In: The Geology of Continental Margins (eds) Burk C A and Drake C L (Berlin: Springer), pp. 873-887.

Todd D K and Mays L W 2005 Groundwater Hydrology; John Wiley \& Sons, Inc., 636p.

USEPA 2001 U.S. National Primary and Secondary Drinking Water Regularizations (NPDWRs); U.S. Environmental Protection Agencies.

Voudouris K S, Lambrakis N J, Papatheothorou G and Daskalaki P 1997 An application of factor analysis for the study of the hydrogeologicai conditions in PlioPieistocene, aquifers of NW Achaia (NW Peloponnesus, Greece); Math. Geol. 29(1) 43-59.

Voudouris K, Panagopoulos A and Koumantakis J 2000 Multivariate statistical analysis in the assessment of hydrochemistry of the Northern Korinthia Prefecture Alluvial Aquifer System (Peloponnese, Greece); Natural Resourc. Res. 9(2) 135-145.

Zaporozec A 1972 Graphical interpretation of water-quality data; Ground Water 10 32-43. 